\title{
The Use of Spanglish in Costa Rican Advertising ${ }^{1}$
}

\section{(El uso del espanglish en la publicidad en CostaRica)}

\author{
Andrew Smith ${ }^{2}$ \\ Universidad Nacional, Costa Rica
}

\begin{abstract}
This paper will study the use of Spanglish in Costa Rican advertising. The significance of this research lies in the fact that although Spanglish is commonly found in Latin American Spanish, especially in advertising, the relationship of these two fields has rarely been analyzed in Costa Rica. Thus, this study can provide important insights into the use of Spanglish and its impact on advertising in commercial and social terms.
\end{abstract}

\section{resumen}

Se examina el uso del espanglish en el lenguaje publicitario en Costa Rica. El valor de esta investigación radica en el hecho de que aunque el espanglish es habitual en el español de América, especialmente en la publicidad, la dinámica de estos dos temas ha sido escasamente analizada en Costa Rica. Por lo tanto, este estudio nos ofrece aportes importantes en el uso del espanglish, y su efecto en la publicidad, en términos comerciales y sociales.

Keywords: Spanglish; the language of advertising; Costa Rican Spanish Palabras clave: espanglish; lenguaje publicitario; español de Costa Rica

1 Recibido: 11 de abril de 2015; aceptado: 26 de julio de 2015.

2 Escuela de Literatura y Ciencias del Lenguaje. Correo electrónico: asmith@ice.co.cr 
Although Spanglish can be defined simply as a mixture of the Spanish and English languages used together, this definition is not complete, nor do scholars agree entirely on what the term refers to; in fact, there are many different perspectives on this topic. ${ }^{3}$ Ilan Stavans, one of the foremost scholars of Spanglish defines it as "The verbal encounter between Anglo and Hispano civilizations." ${ }^{\prime 4}$ Alfredo Ardila calls Spanglish "... a blend (at different degrees) between Spanish and English, which can have an Anglicized Spanish dialect that sometimes may be difficult to understand for standard monolingual Spanish speakers." ${ }^{5}$ Vanessa Parra provides a broader perspective: "Spanglish is a language, lifestyle, and culture that has one foot in each set of traditions. It is a mix of Spanish and English language that is informal and focuses on trends in fashion, music, news, and art that appeals to a person who enjoys aspects of the American and Latino culture. This new culture voices opinions and values that might not be seen as acceptable by Americans or Latinos." In his article "Is 'Spanglish' the third language of the South?: Truth and Fantasy about US Spanish," John M. Lipski shows the complexity of defining the term "Spanglish" when he addresses questions such as the following:

Who uses Spanglish and in what circumstances? [...] When and where is Spanglish used and not used? [...] How is Spanglish acquired? [...] Can Spanglish be characterized technically as a jargon, a pidgin, or a creole language? [...] Does Spanglish have native speakers? [...] Does Spanglish have a common linguistic core, understood and used by all speakers/listeners? [...] Do regional or social dialects of Spanglish exist?

3 Andrew Smith, "Spanglish in Advertising," Revista de Lenguas Modernas 23 (2015): 167-184.

4 Ilan Stavans, Spañglish (New York: Harper Perennial, 2003) 5.

5 Alfredo Ardila, "Spanglish: An Anglicized Spanish Dialect," Hispanic Journal of Behavioral Sciences 27, 1 (2005): 61.

6 Vanessa Para, "Advertising Trends for the Hispanic Market," Other Languages, Societies, and Cultures (2011): 4-5.

7 John Lipski, "Is 'Spanglish' the third language of the South? Truth and Fantasy about US Spanish," $3 r d$ Language Variation in the South (LAVIS III) Conference, Tuscaloosa, AL (2004): 1-3. 
Lipski then goes on to list twenty-eight different "definitions" of Spanglish from different authors and sources, and most of these definitions refer to a mix of Spanish and English. For this article, Spanglish will be used in a very broad sense to refer, as many scholars have accepted, to whenever the Spanish and English languages are "blended" together.

Interestingly, even the name "Spanglish" varies, especially when it is referred to in the Spanish language, in the United States. Some of its in names are: "espanglish" or "engliñol," and "englañol." In Mexico, Ilan Stavans tells us that there are even more names for Spanglish. Some of the terms it is known by are: "espanglés," "casteyanqui," "inglañol," "argot sajón," "español bastardo," "papiamento gringo," or "caló pachuco." 10

The complexity seen in defining and naming Spanglish is also reflected when one attempts to classify it linguistically. One can see the diversity and richness of Spanglish when relating it to some of the distinct fields of linguistics. It is in the field of sociolinguistics since it deals with social factors such as the differences in regional, class and occupational dialects, and is obviously related to bilingualism. Spanglish also has a place in the field of lexicology because with Spanglish one sees the study of formation, meaning, the use of words and idiomatic expressions. Spanglish must also be included in the field of pragmatics, since it concerns social language skills that are used in daily human interactions. What one says and how one says it in given situations, and how these statements are interpreted does concern Spanglish. Spanglish must also be included in the field of text linguistics, since it involves both written and oral texts which can be taken into consideration concerning their respective institutional and social roles.

8 Lipski, 1.

9 Ardila, 63.

10 Ilan Stavans, "Tickling the Tongue," World Literature Today 74, 3 (2000): 555-558. 
Aldredo Ardila is also concerned with the question of how Spanglish should be classified linguistically, and he too, sees the richness and diversity of the concept. For him, Spanglish has certain characteristics of an interlanguage; it can also be called a pidgin language, a Creole language, which is even the native language of many people. ${ }^{11}$

This article presents a study of cases of Spanglish in Costa Rica and in its role in advertising. In sum, it will show how these two languages, English and Spanish, are used together to create a gamut of effects on the consumer. Advertising is not only the action of attracting clients to a product or to a business in order to sell; it has also been considered "the official art of capitalism." 12 Theodor Adorno and Max Horkheimer state that advertising controls society, it controls the consumer, and it even shapes language. ${ }^{13}$ Thus, the two topics, Spanglish and advertising, can be complex, but this research does not delve into each of these concepts individually in depth.

The presence of English in Costa Rica is first noted in 1871 with the arrival of workers who emigrated from the Antilles to work on the railroad in the Atlantic zone. These jobs were well paid, but in spite of the salaries, Costa Ricans did not want to work in the area because yellow fever and malaria were causing problems there at that time. Most of these railroad workers came from Jamaica and were English speakers. They would go to Jamaica to visit their families and many would return to Costa Rica with family members or other immigrants, so in essence, this became a permanent migration of English-speaking people to Costa Rica, and when railroad construction ended in 1890, the majority of these workers remained in the country. Another factor that increased the presence of English in Costa Rica took place during the period of its independence in 1821. Since freedom from Spain also meant no more money from Spain, Costa Rica was forced

11 Ardila, 66

12 David Harvey, The Condition of Postmodernity (Oxford: Blackwell, 1989) 63.

13 T. Adorno \& M. Horkheimer, "The Culture Industry: Enlightenment as Mass Deception," Stardom and Celebrity: A Reader (London and Thousand Oaks, CA: Sage, 2007) 22-23. 
to find other means of funding, and in 1866 signed a contract with the United States government, with the goal of once again working on the construction of the railroad. After this date, Costa Rica signed more contracts with US companies and found itself caught up in the North American economy. Having made these investments, they came to Costa Rica to oversee them, bringing the English language. In addition, when the United Fruit Company began operating in CostaRica at the beginning of the $20^{\text {th }}$ century, there was a second large wave of immigration to Costa Rica. This time, other English-speaking immigrants came from Canada, the United Kingdom and the Unites States, as Virginia Zúñiga Tristán has indicated. ${ }^{14}$

Going back to the $19^{\text {th }}$ century, the presence of English was once again augmented by the process of education. When Costa Rica was given her independence, it was easier for students to go to other countries besides Spain to pursue higher studies. Many Costa Ricans went to England and the United States to study, and returned with their degrees and as well as a good command of the English language. In addition, there were educational institutions in Costa Rica directed by the North Americans, and the classes were imparted almost entirely in English. ${ }^{15}$

Costa Rica became aware of the invasion of many anglicisms in the late 1800s. Zúñiga Tristán has pointed out that because of the British and North American influences, some of the first anglicisms reported were seen in Alberto Brenes Córdoba's book Ejercicios gramaticales (1888), a source that presented the following vocabulary and expressions: clown, God save the King, God save the Queen, Happy New Year, high life, meeting, reporter, self-government, that is the question and time is money. ${ }^{16}$ In 1893, Carlos Gagini published his Diccionario de barbarismos y provincialismos de Costa Rica, which included the

14 Virginia Zúñiga Tristán, El anglicismo en el habla costarricense (San José: Editorial Costa Rica 1976) 21-23.

15 Zúñiga Tristán, 21-23.

16 Zúñiga Tristán, 24. 
following anglicisms: breque, brequero, canfin, chafirrazo, chafirro, cheque, chequear, chinchibí, chumeca, escarchar, lonche, macadam, macadamizar, macadamización, monis, poca, and queque. Interestingly, most of these words were only used in the country. ${ }^{17}$ In 1897 Gagini also published another book entitled Ejercicios de lengua castellana, which included the following new terms that were not found in his previous work: all right, at home, yockey (sic), box, sport, four in hand and forever. ${ }^{18}$ And seven years later, Gagini published another book, $E l$ vocabulario de los niños. Curso superior, which includes the following new anglicisms: bote, biftec, flete, paquete, ron, túnel, rail or riel, révolver, ponche, dogo, tranvía, filibustero, grumete, vagón, balaste, cok, dragar, club, paquebote, lord, rosbif, ténder, tílburi, yarda and yate. Finally, in 1919, Gagini in Diccionario de costarriqueñismos, incorporated an extra thirty-one anglicisms, which were not included in previous works: boxeador, boxear, budín, coctel, champú, donqui, flirtear, macadán, niple, picnic, plash, reportear, reportero, sangüiche, suampo, suich, tanden, flit and yanque. ${ }^{19}$. As we see through the years, the list of anglicisms was increasing and filtering the Costa Rican popular language. A close look at these words shows us that most of these anglicisms were nouns, with the exception of a few expressions.

According to Zúñiga Tristán, these anglicisms were cause for concern. She considers this to be an "invasion," an "epidemic," a "problem," 20 and speaks of the "battle" that was being waged against the "advance of the use of anglicisms" by passing a law to prohibit the use foreign languages on signs and brands in Costa Rica. ${ }^{21}$ One of the chapters in her book is called "Penetración y presencia del inglés." It is interesting to point out that penetration can symbolize violence, or even rape; so for Zúniga Tristán, an English language instructor, the appearance of anglicisms in the Spanish language of Costa Rica was

17 Zúñiga Tristán, 25.

18 Zúñiga Tristán, 25.

19 Zúñiga Tristán, 25.

20 Zúñiga Tristán, 14.

21 Zúñiga Tristán, 15. 
not a positive occurrence. It seems that Zúñiga Tristan was concerned about the identity of Costa Ricans and Costa Rica itself.

Nowadays, many words that native speakersofSpanish believe to be genuine Spanish are in fact anglicisms that have become embedded in the language. Here in Costa Rica, it is common knowledge among language instructors that words like "happy hour," "baby shower" and "coffee maker" are anglicisms. I remember asking a Costa Rican what the correct word for "coffee maker" was in Castilian Spanish, and the person answered "percolador" which in theory, at least according to Zúniga Tristán, is another anglicism. This is not only seen in Costa Rica, as Rose Nash confirms:

Many Puerto Ricans who classify themselves as monolingual speakers of Spanish are quite unaware that some of the words they use naturally and unselfconsciously are English in origin. One of my colleagues at the University of Puerto Rico relates an anecdote about a visitor from Spain who was to give a lecture on the campus. When he asked a campus guard for directions to the paraninfo, the guard replied that he was sorry but he did not understand English. After the visitor clarified what he meant, the guard informed him that the Spanish word for that was asemblyjol (assembly hall). ${ }^{22}$

Spanglish and advertising in Costa Rica have consistently maintained a close relationship for nearly two hundred years. One of the first advertisements found in a newspaper was published on May 23, 1833, in El Noticioso Universal, the first Costa Rican newspaper. Advertising in Costa Rica, as in the rest of the world, continued to grow, and the best-selling newspaper La Información published 1,026 advertisements in $1918 .{ }^{23}$ English was introduced into these advertisements very quickly. For example, on April 30, 1913, on page 2 of $L a$ Información, there is an advertisement for Nestle's Condensed Swiss

22 Rose Nash, "Spanglish: Language Contact in Puerto Rico," American Speech 45, $3 / 4$ (1970): 226. 23 Patricia Vega Jiménez, "Estrategias publicitarias en Costa Rica (1900-1930). Pensar la publicidad," Revista Internacional de Investigaciones Publicitarias 2, 1 (2008): 45-48. 
Milk, with no translation. According to Patricia Vega, the English language is a sign of authority in publicity like this, where the reference to the Swiss Alps can be considered as a guarantee of quality. ${ }^{24}$ Most non-English speakers will understand this sentence, or this product, since "milk" is a common word in English, and the words "condensed" and "Swiss" are transparent. The advertisement thus gains prestige from the English language, without isolating its readers, and in theory the product will sell better than a competing brand of condensed milk from Costa Rica or any other Latin-American country. On May 26, 1915, on page 3 of La Información, an advertisement for "Sunlight Jabón" is another case of Spanglish in advertising and foreign branding. ${ }^{25}$ Here, the word "Sunlight," the original brand name from a British company, is a noun. Some of the packages from before had rays of sun on them, so it is likely that at least some consumers would understand the word, but this is not entirely necessary. Again the foreign word implies quality from a foreign country, and should sell better than a national or more familiar brand.

The products advertised in these first Costa Rican newspapers were products that people needed for their daily life. Today, both English and Spanglish are very prominent in advertising. Even on international television, many of the commercials using Spanglish reach Costa Ricans, such as the popular "Open English" commercials. In fact, Costa Rican television commercials along with advertising in newspapers and in magazines give us a good sample of the use of Spanglish here, as the present study shows. It is pertinent to clarify that the advertisements analyzed were taken from billboards, storefronts and businesses in Costa Rica in the San José metropolitan area. Advertising the newspapers La Nación, La Teja, Diario Extra, and the magazines Summa and Perfil are also used. These advertisements will be analyzed to observe how Spanglish is used, and how it might effect its would-be buyer.

24 Vega, 55.

25 Vega, 54. 
One of the most common advertising techniques using Spanglish is to simply use English words, as seen above, or English words mixed with Spanish to create an exotic effect and thus sell more than competing brands. Teresa Gómez Cerdeño points out that the fact of putting foreign words into an advertisement will appeal to the buyer because the information becomes different and exotic and will therefore be remembered. ${ }^{26}$ For example, a movie being advertised in Costa Rica was called "Maikol Yordan de Viaje Perdido," and this is obviously a Spanglish version of the retired basketball player Michael Jordan's name, done for popularity effect, since most people recognize Jordan's name. Putting his in Spanglish will make the movie more marketable, and hence make more money.

Food is an important part of our life and helps shape our identity; for this reason, many advertisements for food exist in society. An example can be seen in downtown Heredia, where an ice cream parlor advertises an ice cream cone called "Testy Cone." The word "tasty" is spelled incorrectly, but the message is intended to be in English, telling us that the ice cream cone is good, and by using even the misspelled English word will, in theory, be more effective than using the phrase "Cono sabroso." In this case, an adjective is used with a noun, but since the advertisement contains a picture of an ice cream cone, there should be no problem understanding what it is advertising, and again, the foreign language implies quality, whether it is true or not.

The following are additional examples of the use of Spanglish in advertising. In front of the Ministry of Agriculture in "Sabana Oeste," there was a billboard last December advertising Kentucky Fried Chicken, offering a "BIG BOX Navideño" as one of its meals. ${ }^{27}$ Phonetically one might consider that for a Costa Rican, "big box" is more appealing and may seem larger than "caja grande," and it does

26 Teresa Gómez Cerdeño, "The Use of Foreign Words as a Persuasive Tool in Marketing Discourse: The Cultural Stereotype of Global English in Spanish Print Advertising" (M.A. thesis), Universidad Complutense de Madrid (2010) 10.

27 Kentucky Fried Chicken, "BIG BOX Navideño" (Advertisement), Billboard, December 2014. 
give the element of exoticism and dimension. Here, the English adjective "big" is used with the English noun "box" along with the Spanish adjective "Navideño" in an effort to create a pleasing sound. Together with the picture on the advertisement, there can be no confusion for those who do not speak English, and again, the pleasant sound and the exoticism of English are combined with the hope of increasing sales. Another interesting case of using English instead of Spanish is seen in the ice cream parlor "POPS" where many or most words on their menu are in English. This must only be for effect, since this franchise is South American and therefore has no real need to translate the menu from English, as American franchises such as McDonald's, Pizza Hut, or Kentucky Fried Chicken may do. On POPS' menu one finds "Milkshakes," "Sundaes," "Birthday cake," "Cotton Candy" and many other items or flavors in English, probably for reasons of authenticity in the creation of these products and again, to attract clients. ${ }^{28} \mathrm{Here}$ the words used for the items advertised are exclusively nouns. As Taylor has pointed out, these words may have a deeper symbolic meaning than their translations, and the "full impact" of the meaning of the word will be transferred into the advertisement. Thus, the impact of the words "Chocolate Milkshake" seems to be stronger than the one caused by the words "batido de chocolate."

The examples below also involve food in advertising. An advertisement for McDonald's on a billboard near San José reads "Grandes Placeres Cuarto de Libra Tasty." ${ }^{29}$ Again, we have the adjective "tasty" here, but this time with the correct spelling, and it is interesting that one would chose the word "tasty" over "sabroso." In the Latino culture the adjective "sabroso" is a popular word associated with many appealing things besides flavor. There is even a musical group called "Sabroso." "Cuarto de Libra" is a direct translation from "Quarter Pounder," found on the menu at McDonald's in the United States. This

28 POPS, "Milkshakes, Sundaes, Birthday cake, Cotton Candy" (Advertisement). Billboard, December 2014.

29 McDonald's, "Grandes Placeres Cuarto de Libra Tasty" (Advertisement), Billboard. 
direct translation is most likely kept to create an effect of a larger size. "Cuarto de Libra" sounds more appealing than 113 grams, roughly the equivalent of a quarter of a pound, and it also sounds bigger. Using pounds instead of kilograms (in this case grams) also gives the product authenticity, for it is weighed as if it were being eaten in the United States. The slogan that is on the bottom right of the ad, "i'm lovin' it" is slang, and it is one of McDonald's advertising campaigns that has been translated into Spanish and used in advertisements in Latin America as "me encanta." Ironically, by using a sentence with informal English, this strategy produces the effect of exoticism and legitimacy, and as always, has the goal of increasing sales.

Other examples of food advertising with English words are used to create a specific effect or indicate larger size, exoticism, intensified flavor or import quality. In the Diario Extra of December 23, 2014, we find an ad for "Cinema Plus," with the following sentence: " $2 \mathrm{x} 1$ Full Nachos con Pollo." ${ }^{30}$ The adjective "Full" gives the idea of plentitude, a large size, and is a word that many Costa Ricans know. In La Teja, of December 23, 2014, we find in an ad for Kentucky Fried Chicken for a meal that says: "4 piezas de pollo... +2 biscuits." 31 The noun "biscuit" is actually a French word that worked its way into the English language, meaning "twice cooked." In the case of the ad, "biscuit" probably gives more of an effect of being more exotic than "galleta," "bollo," or "bizcocho," which are possible translations for "biscuit," and again the goal is to increase sales. In the magazine Perfil \#668, April, 2014, publicity for Zaragozo lunch meats says: "Probá los nuevos Chorizos, Roast Beef y Especialidades Zaragozo. ¡Un gusto a tu paladar!”32 In a Spanish dictionary, the translation for the compound noun "roast beef" is "rosbif," which itself could be considered Spanglish, but by using the "correct" English here, they

30 Cinema Plus, "2x1 Full Nachos con Pollo" (Advertisement), Diario Extra, 23 December 2014.

31 Kentucky Fried Chicken, "4 peizas de pollo + 2 biscuits" (Advertisement), La Teja, 23 December 2014.

32 Zaragoza, "Probá los nuevos Chorizos Roast Beef y Especialidades" (Advertisement), Perfil 668, April (2014): 33. 
are attempting to produce an effect of import quality to sell more. Sometimes these words are compound words, such as those found in La Nación of December 5, 2014, where the restaurant Spoon offers a "Six Pack de Tamales + Café Britt Holiday Blend 340 g." 33 This advertisement catches the reader's attention by using the English noun "six pack" in a different context. A six pack is normally used for beer or soft drinks, and it adds the words "Holiday Blend," a shorter phrase that is possibly more attractive to the eye than something like "Mezcla para día de Fiesta."

The English language is sometimes not just inserted into the advertisement as isolated words but rather directly into a phrase in Spanish, as if it were a Spanish word. In Perfil magazine \#668, from April 2014, on page 27, an advertisement for shoes reads "Obsesión por el comfort." 34 Most non-English-speaking readers will probably recognize the noun "comfort" as "comodidad" o "bienestar"; the line of shoes is called "natural comfort." Again, this English word, inserted into the Spanish phrase as if it were a Spanish word, will capture the reader's attention. Another interesting case of Spanglish is seen in the idea of Santa Claus. In Revista Dominical in La Nación of December 21, 2014, an advertisement for the program "Alo Santa" reads: "No importa lo que pasa, Santa llamará a tus hijos." ${ }^{35}$ Santa Claus represents much more than a mere six pack or comfort, roast beef or biscuits. Why would advertisers want to change a whole cultural icon from "San Nicolás" or "Papá Noel" to Santa? It is just one word, and therefore shorter, but with such an important cultural icon, one would assume that a country would conserve its original form. Possibly, with all of the advertisements and influence from the Unites States, it has also become embedded into the culture. In La Nación of December 21, 2014, publicity for Radio Shack reads: "Ho, Ho, Ho!

33 Spoon, "Six Pack de Tamales + Café Britt Holiday Blend 340 g" (Advertisement), La Nación, 5 December (2014): 35A.

34 Natural Comfort, "Obsesión por el comfort" (Advertisement), Perfil 668, April (2014): 27.

35 Alo Santa, "No importa lo que pasa, Santa llamará a sus hijos" (Advertisement), La Nación, Revista Dominical, 21 December 2014. 
Esta Navidad Conectá con Todos." ${ }^{36}$ In Spanish, this could be "Jo, Jo, Jo." So, Santa Claus and his laughing "Ho, Ho, Ho," do seem to form part of the Costa Rican culture and language used. It is not only the visual image, but the sensorial complement of the laughing that have been adopted and used by Costa Rican advertisers.

The Spanglish combinations found in Costa Rican advertisements sometimes make no real sense, but this could be a questionable choice when dealing with speakers of Spanglish, since they are sometimes sensitive to how Spanglish is used and can be offended if it is used disparagingly, as Gloria Anzaldúa said: "If you want to really hurt me, talk badly about my language. Ethnic identity is twin skin to linguistic identity - I am my language. Until I can take pride in my language, I cannot take pride in myself." ${ }^{37}$ Latinos do not appreciate it when their language is made fun of or badly represented. Karla Michelle Esquivel reiterates this idea when she states:

Hispanics will take very strong note of what exactly the brand is doing and if they can relate to the product. At times, if a brand in some way offends the Hispanic culture or simply what one individual finds offensive, then the feelings towards that brand change. This could be said for any consumer group or individual, but in the case of Hispanics they are very proud of their heritage and do not take insult or offense very lightly. ${ }^{38}$

In Costa Rica, many of the advertisements in real-estate publications or in magazines such as Summa are targeting either North American investors or other wealthy English speakers, who may simply ignore the nonsensical English. This can be exemplified by publicity in Summa, edition \#170 of July, 2008, where we find an ad

36 Radio Shack, "Ho, Ho, Ho! Esta Navidad Conectá con Todos" (Advertisement), La Nación, 21 December 2014.

37 Gloria Anzaldúa, Borderlands: la Frontera. The New Mestiza (San Francisco: Aunt Lute Books, 2012) 81.

38 Karla Michelle Esquivel, "Code Switching: How Latinos Are Changing Advertising and the Spanish Language" (thesis), University of Texas at Austin (2012) 8-9. 
for the STT group, a multinational company that offers such services as marketing and legal advice. At the end of their advertisement, they state: "STT Group, Supplying Total Total." 39 This sentence makes no sense whatsoever. Possibly the repetition of the adjective or noun "Total" is visually and phonetically pleasing. Another similar example is found elsewhere in the magazine, where an ad for the Crowne Plaza hotel shows a woman comfortably sleeping in a bed with the caption beneath the picture saying "Encuentre esto y mucho más. These and More. ${ }^{" 40}$ In this example, the expression: "These and More" is adding nothing to the previous sentence written in Spanish. It looks good here because it is in English, but there is no new content, no message. Besides, the plurality of the word "these" is never clarified.

Another Spanglish strategy seen in Costa Rican advertising is to write one part of the ad in Spanish and the other part in English. In Summa, edition \#170, of July 2008 in an advertisement for Bayer, a chemical-pharmaceutical company, the ad has a large picture of a young boy drinking water out of his hands, and the message is: "Actuar con Responsabilidad.....Crear Oportunidades... Science for a Better Life." ${ }^{41}$ This is followed by a long text of over 220 words written entirely in Spanish, telling the reader all of the wonderful things that Bayer is doing for humanity. At the bottom of the text, it ends with: "Bayer: HealthCare....CropScience.....MaterialScience." One can assume that the strategy applied here is to capture the attention of both Spanish and English readers, since the headlines are in both Spanish and English. Possibly, the idea is that the Spanish speaker will understand the few words in English, and can then read the Spanish text. Since the Spanish words are cognates and transparent, readers of English will understand that Bayer is "acting responsibly" and "creating opportunities." Here, Spanglish is being used to make

39 STT, "STT Group, Supplying Total Total" (Advertisement), Summa 170, July (2008): 35.

40 Crown Plaza Hotel, "Encuentre esto y mucho más. These and more" (Advertisement), Summa 170, July (2008): 51.

41 Bayer, “Actuar con Responsabilidad” (Advertisement), Summa 170, July (2008): 71. 
certain that a high number of readers will be able to understand the positive message, and again purchase the product.

Another example of mixing Spanish and English is seen in a full-page advertisement taken from the Revista Dominical ( $\mathrm{La}$ Nación), on December 7, 2014 by the Pan-American School. ${ }^{42}$ This publicity consists of a congratulatory message for winners of national and international sporting events. All of the headlines are in English: "PROUD OF OUR WINNERS National Competitions"; that is followed by the names of nine students who won national sporting events. All of this section is written in Spanish. The second part of the ad says, "International Competitions," which is again followed by nine groups of students or individual students who won international sporting events, and again this is all in Spanish, with English words such as "Downhill" and "Bowling." The third and final part of the ad says, "We also congratulate our Generation 2014 for 100\% Promotion in High School and MEP Bachillerato Diplomas," followed by the name of the valedictorian and the salutatorian. Why did writers of this advertisement decide not to translate the sporting events into English? Here, it is probably more reasonable to conserve the Spanish version since the sporting events took place for the most part in Costa Rica or in Latin America. The only exception was one competition in Miami, a place with a large Spanish-speaking community. But why would they use English in some part of the ad? Because this school, the PanAmerican School, is bilingual, and thus it is prestigious to have the ad in English. The sporting events took place in a Spanish-speaking environment, and all the readers may not speak English, but they will be able to appreciate who won what event. Again, it is a manipulative game, since both Spanish and English are used for specific effects: identification or prestige in the same ad, where both languages are combined. Here, the goal is most likely to attract parents and entice them into sending their children to this bilingual school.

42 Pan-American School, "PROUD OF OUR WINNERS National Competitions" (Advertisement), La Nación, Revista Dominical, 7 December 2014. 
Finally, the last part of this advertisement, "...for $100 \%$ Promotion in High School and MEP Bachillerato Diplomas," also deserves to be analyzed. First of all, the Spanish word "Bachillerato" is not necessary and makes the translation sound bad, like incorrect English. A bachillerato is a high school diploma, so this wordcould have simply been eliminated, to avoid the awkward construction. Secondly, the " $100 \%$ Promotion" is a Spanish concept that has been directly translated into English, but incorrectly. A correct translation would refer to the fact that no one failed or that everyone passed and could graduate. The use of a Spanish construction in English (for a Spanish-speaking readership) can be considered, according to Rosaura Sánchez, a form of Spanglish. ${ }^{43}$

In the magazine Perfil \# 646 of August, 2012, an advertisement for perfume and lingerie for Victoria's Secret features a very attractive woman, shown from the waist up, wearing a colorful brassiere. There are three bottles of perfume beside her, and the ad reads in very large letters: "What's Sexy Now?" Then, in smaller letters there is the phrase: "Regalos que Nos Encantan para Ella." At the bottom of the ad, underneath the perfume bottles, the phrase "Victoria's Secret Beauty and Accessories" appears. ${ }^{44}$ What captures the attention in this ad is obviously the beautiful woman in a brassiere, but besides this, the huge letters next to her face that ask "What's Sexy Now?" also capture one's attention. This question is probably understood by most readers, or at least the word "Sexy" will be understood by everyone, especially combined with the photo. The combination of the sexy woman and the huge letters in English works very well together. There is really no message here; the woman sells the product. What is sexy now is the woman herself: Sex sells and Spanglish sells, so together they must sell even more.

A close analysis of these examples shows us that the English language is mainly used to create an effect on the consumer: to fulfill

43 Ilan Stavans, ed., Spanglish (Westport: Greenwood Publishing Group, 2008) 29.

44 Victoria's Secret, "What's Sexy Now?" (Advertisement), Perfil 646, August (2012): 79. 
a need or to reinforce one, to arouse identification or to create a bond, to appeal to popularity, exoticism, or social prestige, or to refer to an increase in the size or flavor of a food product. So, this effect may simply be that of changing a word or name, such as "Michael Jordan" to "Maikol Yordan." This is done to give importance or exoticism to the product and makes it easier to remember. Another technique is simply to translate the English word into Spanish as seen in the cases of a "Cuarto de Libra" for a "Quarter Pounder." Since grams and kilograms are used in Costa Rica, rather than ounces or pounds, this technique is again making the product more exotic, more legitimate. This search for the exotic may also take the form of using a slogan such as 'i'm lovin' it" instead of the corresponding Spanish slogan of "me encanta." This game is risky because not everyone in Costa Rica speaks English. Yet it probably is worth the risk since most non-English-speaking people will recognize the verb "love" in this slogan, and together with the iconic golden arches of the McDonalds, a message of something "good" is communicated. The same applies to the examples of "biscuit," "six pack" and "Holiday Blend" discussed above.

When an English word is simply inserted into an ad in an otherwise Spanish-language text, such as "Obsesión por el comfort" or "Probá los nuevos Chorizos, Roast Beef y Especialidades Zaragozo,", or " $2 \mathrm{x} 1$ Full Nachos con pollo," the effect is even stronger because the foreign word is being used exactly as if it were a Spanish word, and thereby making it even more a part of the language, again increasing its legitimacy within the linguistic structure itself, and contributing to the construction of personal identity of the readers who understand English and can consider themselves bilingualreaders and or speakers.

This legitimacy and exoticism may include more than mere words or phrases even cultural icons such as "Santa" for "Papá Noel" and "Ho ho ho" for "Jo jo jo." Maybe Santa is easier to say than Papá Noel, maybe the whole idea of exotic freezing weather and snow is included in these anglicized versions. And when the message makes no real sense in English, such as the examples of "STT Group, Supplying 
Total Total" and "Encuentre esto y mucho más. These and More," at least the English form is present, repeating the Spanish message, and imposing itself on the reader. If this reader does not understand, he or she may even feel guilty, since speaking English is nowadays considered "necessary" in the labor market. The reader will subconsciously give more credit to the advertisement, which in reality is saying very little by inserting the foreign words.

In conclusion, Spanglish is very prominent in Costa Rica, both in the culture and especially in advertising. As shown above, Spanglish in advertising has been used since the early 1900's and its influence has grown rapidly and in different forms: English is used with Spanish, many times with isolated words or combined forming new words, or it is inserted directly into a Spanish sentence. Even though on some occasions English used along with Spanish makes no sense, it does create an effect, supposedly giving prestige to the product advertised. At times one part of the advertisement is written in English and another part in Spanish, and sometimes Spanish terms are translated literally and incorrectly into English. Will Spanglish continue to grow in Costa Rica? Yes, it probably will, due to the media: international television, movies and the Internet. Will it threaten the Spanish language and become another language of its own? Time will tell. As Ilan Stavans says, "It's too early to say. Languages develop over long periods of time. However, [...] the speed with which fresh Spanglish terms are disseminated these days is astounding. ${ }^{~} 45$ However, Ardila maintains that since Spanglish is often more difficult to speak than Spanish, and requires years of practice, it is unlikely that it will not become a distinct, genuine language. ${ }^{46}$

In Costa Rica, it is unlikely that Spanish will be replaced or grotesquely bastardized by the English language, due to the high level of education that many Costa Ricans enjoy. Upper and middle class Costa Ricans can use formal Spanish appropriately, and many also speak

45 Stavans, ix.

46 Ardila, 78. 
correct English, so sometimes they use English words when they are speaking Spanish. It seems more likely that Spanglish will continue to be used as it is now, in the press, for advertisements to sell products, and as a game or a joke, in expressions such as "OK," "sorry," or "thank you." Nevertheless, one cannot ignore words that have become part of the language, words that people believe are Spanish and which are not. But again, can one not say that this is normal? Languages change and evolve with time, and every language has its foreign words that help enrich the language itself and provide it with variety.

The English language is a part of Costa Rican culture but does not control or dominate it; English goes along with this culture and in the process, Costa Rican culture is transformed. At the present time, where diversity and dynamism are undeniable components, the use of languages, and their mixtures and combinations, is not rare. Multiculturalism, internationality, globalization are terms that associate different languages, as well as cultures, societies and human needs. Advertising looks for needs, intensifies them and profits from them. Spanglish is a means of developing these marketing strategies, and in Costa Rican advertisements, Spanglish plays an important role and appears to have a secure place. 